\title{
The Impact of Cultivation of Medicinal Plants on the Economic Income of Rural Settlements Case study of Kalat city villages
}

\section{El impacto del cultivo de plantas medicinales en los ingresos económicos de los asentamientos rurales Estudio de caso de los pueblos de la ciudad de Kalat}

\author{
Mansoureh Alipour Khesht \\ PhD Student, Department of Geography and Rural Planning, Mashhad Branch, Islamic Azad \\ University, Mashhad, Iran \\ ORCID: https://orcid.org/0000-0003-1892-4714 \\ Hamid Jafari \\ Department of Geography, Mashhad Branch, Islamic Azad University, Mashhad, Iran \\ ORCID: https://orcid.org/0000-0002-2007-562X

\section{Katayoun Alizadeh} \\ Department of Geography, Mashhad Branch, Islamic Azad University, Mashhad, Iran \\ ORCID: https://orcid.org/0000-0001-7875-0977
}

*Correspondence

Email: hamidjafari@yahoo.com
Cite as:

Alipour, M., Jafari, H., \& Alizadeh, K. (2021). The effect of cultivation of medicinal plants on the economic development of rural settlements Case study: Villages of Kalat city. Propósitos y Representaciones, 9 (SPE2), e957. Doi: http://dx.doi.org/10.20511/pyr2021.v9nSPE2.957 


\section{Summary}

Medicinal plants, as part of natural resources, have been one of the most important sources of human food and medicine for generations. Diversification of the rural economy is considered as a tool to accelerate economic development at various levels, this approach is considered as one of the most important strategies for the development and economic sustainability of rural settlements in Iran, because it has a great effect on promoting the welfare and security of the region's economy. According to the economic policies of the country based on the development of non-oil exports, it is necessary to pay attention to the export of agricultural products, therefore, by planting valuable medicinal species, it is possible to plan the texts, while developing the economy and provision the needs of domestic industries, and it also earned significant foreign exchange earnings from the export of medicinal plant products. The aim of this study was to investigate the effect of cultivation of medicinal plants on the economic development of rural settlements (case study of villages in Kalat city). The present research is applied in terms of purpose and is descriptive-analytical in terms of method. The sample population includes 7 villages of Kalat city (Abgarm, Aghdash, Qara Tikan, Garou, Qoleh Zoo, Sini and Soroud) with 1589 families, which amount to 5283 people. According to the research results, planting medicinal plants, on average, generates 523.6 more in revenue generation than planting crops.

Keywords: Medicinal plants, Rural economy, Income generation, Rural settlement development, Rural sustainability, Kalat city.

\section{Resumen}

Las plantas medicinales, como parte de los recursos naturales, han sido una de las fuentes más importantes de alimento y medicina humana durante generaciones. La diversificación de la economía rural se considera una herramienta para acelerar el desarrollo económico en varios niveles, este enfoque se considera una de las estrategias más importantes para el desarrollo y la sostenibilidad económica de los asentamientos rurales en Irán, porque tiene un gran efecto en la promoción de la bienestar y seguridad de la economía de la región. De acuerdo con las políticas económicas del país basadas en el desarrollo de las exportaciones no petroleras, es necesario prestar atención a la exportación de productos agrícolas, por lo tanto, mediante la siembra de valiosas especies medicinales, es posible planificar los textos, mientras se desarrolla el economía y abastecimiento de las necesidades de las industrias nacionales, y también obtuvo importantes ingresos en divisas de la exportación de productos de plantas medicinales. El objetivo de este estudio fue investigar el efecto del cultivo de plantas medicinales en el desarrollo económico de los asentamientos rurales (estudio de caso de pueblos en la ciudad de Kalat). La presente investigación se aplica en términos de propósito y es descriptivo-analítico en términos de método. La población de muestra incluye 7 aldeas de la ciudad de Kalat (Abgarm, Aghdash, Qara Tikan, Garou, Qoleh Zoo, Sini y Soroud) con 1589 familias, que suman 5283 personas. Según los resultados de la investigación, plantar plantas medicinales, en promedio, genera 523,6 más en generación de ingresos que plantar cultivos.

Palabras clave: Plantas medicinales, Economía rural, Generación de ingresos, Desarrollo de asentamientos rurales, Sostenibilidad rural, Ciudad de Kalat.

\section{Introduction}

One of the ways to reduce the pressure on nature and create diverse and double income in rural 
communities is the approach of planting and producing medicinal and industrial plants in eligible areas. Establishing farms of medicinal plants in rainfed conditions or low-yield lands and sometimes allocating national lands around villages to plant medicinal plants has many benefits. These benefits include: saving agricultural water consumption, reducing pressure on nature, protecting water and soil, creating employment and diversified incomes, reducing migration, activating the rural economy, supplying medicinal plants needed by drug companies, Currency and increase non-oil exports and improve the environment, development of tourism and rural ecotourism industry, guarantee the preservation of plant species diversity and genetic resources and other benefits. (Tarhani, 2015: 9).

In many developing countries, herbal medicine is recognized as an important part of their treatment system. According to the World Health Organization, more than $80 \%$ of the world's population uses 200 types of drugs to treat their diseases and more than $30 \%$ of the world's plant species are used for medicinal purposes. $25 \%$ of all drugs used in developed countries and more than $80 \%$ of drugs used they are of plant origin in China and India. The extinction of plant species can have profound and negative effect on the inhabitants of the planet, as in medical science, the extinction of these plant species is an opportunity to discover and treat many diseases, ultimately treatment management will eliminate these diseases. In all societies, biodiversity is considered a national treasure and conservation of biological resources will lead to effective exploitation and scientific application of them in the future (Sen Samanta, 2014: 3).

Cultivation of medicinal and aromatic plants has long had a special place in the traditional agricultural systems of Iran and these systems have played an important role in creating diversity and sustainability. Unfortunately, in recent years, due to the replacement of improved crop species with high yield and economic value, many of these local and indigenous species and cultivars have been forgotten and they have been removed from Iranian agricultural systems (Kouchaki et al., 2004: 209). In fact, with the domestication and planting of valuable medicinal species can be collected through planning, while economic development and provision the needs of domestic industries and also, earning significant foreign exchange earnings from the export of herbal medicinal products, played an effective role in protecting the germplasm reserves of its natural habitat (Fattahi and Fattahi, 2010: 127).

Due to the increasing demand for medicinal plants in Iran and the world, the cultivation and processing of these products is of particular importance. Cultivation of some medicinal plants due to compatibility and optimal yield (low water requirement in drought conditions of the country and also the ability to produce in low-interest areas) can be effective in increasing the productivity of water and soil resources.

Iran has special capacities and talents in the field of production of medicinal plants which has received less attention and Khorasan Razavi province is the first in the country in the field of production of medicinal plants and Kalat city has the first place in Khorasan Razavi province in the field of production of medicinal plants.

Due to the major problems of the study area, including:

Unfavorable climatic conditions such as drought, flood and cold;-

-limitations on employment, unemployment and lack of complementary activities of production, marketing and price fluctuations of agricultural products ;

-Extensive population migrations so that the population of Kalat city according to the 2006 census was 40 thousand people, which in the 2011 census decreased to 38 thousand people and in the 2016 census decreased to 36 thousand people.

Due to the problems in the field of climate, economic activities and soil and water shortages in the study area through the production and cultivation of medicinal plants, it is possible to help to 
the sustainable development of the country and the sustainability of the population in rural settlements.

The main question of the present research is:

What is the production status of medicinal plants in terms of income compared to other crops in the study area?

\section{Theoretical foundations of research}

Agriculture is the most important activity in rural areas, which is traditionally done in rural areas of Iran. Such economic and employment structure in rural areas has led to certain issues. Problems in urban areas can only be solved by creating job opportunities in rural areas. Creating various jobs by diversifying activities in rural areas can solve many problems in these areas (Matiei Langroudi et al., 2019: 1) Therefore, diversification of economic activities as a fundamental strategy in developed and developing countries and has been emphasized and considered by international organizations. Economic diversity is even more important in areas where the economy relies on unit cultivation. Creating non-agricultural employment, in addition to strengthening the foundations of the rural economy, will prevent rural migration. Providing a structure for various economic activities will not only reduce the problems of cities, but also bring the quality of rural life closer to the quality of urban life, and finally, it will facilitate the process of rural development (Javan et al., 2011: 43).

One of the ways to create diversity in the one-dimensional economy of villages is to pay attention to the planting and exploitation of medicinal plants, which include various types of plants, which have effective pharmaceutical compounds and are widely used in the pharmaceutical industry (Ahmadian Shalchi, 2014: 98). Annual consumption of medicinal plants in European industrialized countries increased by between seven and a half to eight percent from 1980 to 1985 . Global statistics also show that the active ingredients of about fifty percent of the drugs offered to the pharmaceutical market are of natural origin, and in some countries this figure has reached ninety percent. In addition, the use of medicinal and aromatic plants among the people of developed countries is increasing rapidly, so that now ninety percent of the people of these countries use herbal medicines (Bernath, 1990: 7-15).

The high participation of rural women in various agricultural and handicraft activities has been associated with providing a significant percentage of household income (Heidari and Jahannama, 2003: 143). Cultivation and collection of medicinal plants can increase income, create financial control, production skills and economic participation by creating new opportunities for rural women and girls. Cultivation of medicinal plants in small plots of land or cultivation as a by-product in orchards and farms, as well as collecting automotive medicinal plants from plains, pastures and forests, since it does not require much capital and factors of production and it is also commensurate with the ability of rural women, it can be effective in improving the economic empowerment of rural women (Heidari and Jahannama, 2003: 152). 
Table 1.

History of Research

\begin{tabular}{|c|c|c|c|c|c|}
\hline $\begin{array}{l}\text { Author / } \\
\text { authors }\end{array}$ & $\begin{array}{l}\text { Year of } \\
\text { publication }\end{array}$ & Title & $\begin{array}{l}\text { Research } \\
\text { type }\end{array}$ & Publisher & Result \\
\hline Afshar & 2016 & $\begin{array}{l}\text { Feasibility } \\
\text { study of entry } \\
\text { of medicinal } \\
\text { plants into the } \\
\text { pattern of } \\
\text { cultivation and } \\
\text { creation of } \\
\text { related } \\
\text { conversion } \\
\text { industries (Case } \\
\text { study: Rural } \\
\text { settlement of } \\
\text { Chenaran city) }\end{array}$ & Thesis & $\begin{array}{l}\text { Mashhad } \\
\text { Ferdowsi } \\
\text { University }\end{array}$ & $\begin{array}{l}\text { Due to water } \\
\text { constraints, the } \\
\text { cultivation of } \\
\text { medicinal plants } \\
\text { and processing } \\
\text { industries play an } \\
\text { important role in } \\
\text { increasing } \\
\text { farmers' incomes }\end{array}$ \\
\hline $\begin{array}{l}\text { Omid } \\
\text { Beygi }\end{array}$ & 2011 & $\begin{array}{l}\text { Findings } \\
\text { production and } \\
\text { processing of } \\
\text { medicinal } \\
\text { plants }\end{array}$ & Book & $\begin{array}{l}\text { Tehran Fekre } \\
\text { Roz }\end{array}$ & $\begin{array}{l}\text { The importance } \\
\text { of processing } \\
\text { medicinal plants }\end{array}$ \\
\hline Tarhani & 2015 & $\begin{array}{l}\text { Diversification } \\
\text { of rural } \\
\text { economy with } \\
\text { the approach of } \\
\text { producing } \\
\text { medicinal } \\
\text { plants (Case } \\
\text { study of } \\
\text { villages in } \\
\text { Quchan city) }\end{array}$ & Thesis & $\begin{array}{l}\text { Islamic Azad } \\
\text { University, } \\
\text { Mashhad } \\
\text { Branch }\end{array}$ & $\begin{array}{l}\text { Diversification of } \\
\text { economic } \\
\text { activities is } \\
\text { effective in } \\
\text { creating jobs and } \\
\text { preventing } \\
\text { migration of } \\
\text { villagers in the } \\
\text { region }\end{array}$ \\
\hline $\begin{array}{l}\text { Kashfi } \\
\text { Banab }\end{array}$ & 2009 & $\begin{array}{l}\text { Comparative } \\
\text { economic } \\
\text { advantage of } \\
\text { cultivation and } \\
\text { trade } \\
\text { medicinal of } \\
\text { plants in Iran } \\
\text { and its value in } \\
\text { world markets }\end{array}$ & Article & $\begin{array}{l}\text { Green } \\
\text { Biology } \\
\text { Magazine }\end{array}$ & $\begin{array}{lr}\text { Cultivation and } \\
\text { development of } \\
\text { medicinal plants } \\
\text { play an important } \\
\text { role } \\
\begin{array}{lr}\text { community } \\
\text { health, } \\
\text { creation job } \\
\text { increasing non- } \\
\text { oil exports }\end{array}\end{array}$ \\
\hline Lebaschi & 2018 & $\begin{array}{l}\text { Water crisis and } \\
\text { the need to } \\
\text { develop the } \\
\text { cultivation of } \\
\text { medicinal } \\
\text { plants }\end{array}$ & Article & $\begin{array}{l}\text { Agricultural } \\
\text { Research, } \\
\text { Education } \\
\text { and } \\
\text { Extension } \\
\text { Organization }\end{array}$ & $\begin{array}{l}\text { Development and } \\
\text { cultivation of } \\
\text { medicinal plants } \\
\text { will be an } \\
\text { effective solution } \\
\text { for optimal use } \\
\text { and saving of } \\
\text { agricultural water }\end{array}$ \\
\hline
\end{tabular}




\begin{tabular}{|c|c|c|c|c|c|}
\hline & & & & & consumption \\
\hline $\begin{array}{l}\text { Yasori and } \\
\text { Javan }\end{array}$ & 2015 & $\begin{array}{l}\text { Analysis of the } \\
\text { limitations of } \\
\text { diversification } \\
\text { of rural } \\
\text { economy Case: } \\
\text { Upper Eshkor } \\
\text { village }\end{array}$ & Article & $\begin{array}{l}\text { Quarterly } \\
\text { Journal of } \\
\text { Economics, } \\
\text { Space and } \\
\text { Rural } \\
\text { Development }\end{array}$ & $\begin{array}{l}\text { Diversification of } \\
\text { rural economic } \\
\text { activities } \\
\text { becomes a } \\
\text { solution for rural } \\
\text { employment and } \\
\text { income and } \\
\text { sustainable } \\
\text { development }\end{array}$ \\
\hline
\end{tabular}

\section{Introducing the study area}

Kalat city with an area of about 3502/962 square kilometers is one of the cities of Khorasan Razavi province and is located in the northeast of Mashhad. It is limited to Turkmenistan from the north, Sarakhs city from the east, Mashhad and Chenaran cities from the south and Dargaz city from the west. The average altitude of this city is 780 meters above sea level, which is 3040 meters in the west side of the city, which decreases in height to the east. Kalat city has two parts (Markazi and Zavin) and four villages (Hezar Masjed, Kaboud Gonbad, Zavin and Pasakuh) and two cities of Kalat and Zavin and 63 inhabited villages. In 2016, Kalat city had 24805 rural population and 11432 urban population (Statistical Yearbook of Khorasan Razavi Province, 2016).

\section{Methods}

The present research is applied in terms of purpose and descriptive-analytical in terms of method. The theoretical framework of the present study is based on the documentary method and in a case study related to the cultivation of medicinal plants in the region, the survey method has been used that the required information has been collected in the form of face-to-face visits to the studied villages, visits to agricultural jihad offices, health center, Kalat city governorate and interviews with experts and exploiters. The sample population includes 7 villages of Kalat city with 1589 families, which are 5283 people. These villages are: Abgarm, Aghdash, Qara Tikan, Garou, Qoleh Zoo, Sini and Soroud. In the present study, income variable is considered as an independent variable and rural economy is also considered as a dependent variable.

\section{Results}

\section{Medicinal plants of the study area}

Proper rainfall and pristine mountains in the four season's nature of Kalat city has created rich and unique pastures and vegetation. The most important forests and vegetation of Kalat Nader Abat are from Sistan forest, Aras forest, Hezar Masjed, Khajeh pistachio forest, Yak berry, etc. Some types of vegetables such as mint are also available naturally and people make money in addition to selling it for personal use. Types of medicinal plants such as Barhang, hedysarum, peppermint, purslane , London rocket seeds, chicory, Borage, sagebrush, lavender, licorice, yarrow, sagebrush, marshmallow, anchovy, sage, thyme, black cumin, balango or the local socalled melango and cockati They are plants found in Kalat. The most important medicinal plants in the studied villages are given in Table 2. 
Table 2.

Status of medicinal plants in sample villages in 2018

\begin{tabular}{|l|l|l|}
\hline Row & Product Name & $\begin{array}{l}\text { Area under cultivation } \\
\text { (hectares) }\end{array}$ \\
\hline 1 & Chia & 2600 \\
\hline 2 & Cumin & 85 \\
\hline 3 & Sesame & 5500 \\
\hline 4 & Barhang & 2 \\
\hline 5 & Rosemary & 2 \\
\hline 6 & Lavender & $2 / 0$ \\
\hline 7 & Thyme Garden & 1 \\
\hline 8 & Peppermint & 1 \\
\hline & total & $2 / 8191$ \\
\hline
\end{tabular}

Source: Agricultural Jihad of Kalat County 2019

\section{Agriculture}

Agriculture is a branch of agricultural science that discusses the principles and operations of farm management to produce crops. (Mazaheri et al., 2001: 11) Agriculture is more important among the agricultural sectors of Iran and it can be said that in most villages, the largest share of household income is provided from agriculture (Taghavi, 2009: 112).

\section{Income and employment of agriculture}

Table 3.

Income from major crops in sample villages During the cropping year 2018-2019hectares / Tomans

\begin{tabular}{|l|l|l|l|l|l|l|l|l|l|l|}
\hline $\begin{array}{l}\text { The } \\
\text { prod } \\
\text { uct }\end{array}$ & $\begin{array}{l}\text { Area } \\
\text { under } \\
\text { cultiva } \\
\text { tion }\end{array}$ & $\begin{array}{l}\text { Opera } \\
\text { tion } \\
\mathrm{kg} \\
\text { (hecta } \\
\text { re) }\end{array}$ & $\begin{array}{l}\text { Cost } \\
\text { per } \\
\text { hectar } \\
\mathrm{e}\end{array}$ & $\begin{array}{l}\text { Unit } \\
\text { pric } \\
\mathrm{e}\end{array}$ & $\begin{array}{l}\text { Impur } \\
\mathrm{e} \\
\text { incom } \\
\mathrm{e} \text { per } \\
\text { hectar } \\
\mathrm{e}\end{array}$ & $\begin{array}{l}\text { Net } \\
\text { incom } \\
\mathrm{e} \text { per } \\
\text { hectar } \\
\mathrm{e}\end{array}$ & $\begin{array}{l}\text { Total net } \\
\text { income }\end{array}$ & $\begin{array}{l}\text { House } \\
\text { hold } \\
\text { share }\end{array}$ & $\begin{array}{l}\text { Work } \\
\text { ing } \\
\text { day } \\
\text { requi } \\
\text { red }\end{array}$ & $\begin{array}{l}\text { Work } \\
\text { ing } \\
\text { day } \\
\text { creat } \\
\text { ed }\end{array}$ \\
\hline $\begin{array}{l}\text { Whe } \\
\text { at }\end{array}$ & 3262 & 1400 & $\begin{array}{l}1 / 165 / \\
000\end{array}$ & $\begin{array}{l}2 / 70 \\
0\end{array}$ & $\begin{array}{l}3 / 780 / \\
500\end{array}$ & $\begin{array}{l}2 / 615 / \\
000\end{array}$ & $\begin{array}{l}8 / 530 / 130 \\
/ 000\end{array}$ & $\begin{array}{l}5 / 368 / \\
238\end{array}$ & 10 & $\begin{array}{l}3262 \\
0\end{array}$ \\
\hline $\begin{array}{l}\text { Barl } \\
\text { ey }\end{array}$ & 895 & 1300 & $\begin{array}{l}1 / 165 / \\
000\end{array}$ & $\begin{array}{l}2 / 20 \\
0\end{array}$ & $\begin{array}{l}2 / 860 / \\
000\end{array}$ & $\begin{array}{l}1 / 695 / \\
000\end{array}$ & $\begin{array}{l}1 / 517 / 025 \\
/ 000\end{array}$ & $\begin{array}{l}954 / 70 \\
4\end{array}$ & 10 & 8950 \\
\hline
\end{tabular}




\begin{tabular}{|l|l|l|l|l|l|l|l|l|l|l|}
\hline Pea & 60 & 600 & $\begin{array}{l}1 / 155 / \\
000\end{array}$ & $\begin{array}{l}8 / 00 \\
0\end{array}$ & $\begin{array}{l}4 / 800 / \\
000\end{array}$ & $\begin{array}{l}3 / 645 / \\
000\end{array}$ & $\begin{array}{l}218 / 700 / 0 \\
00\end{array}$ & $\begin{array}{l}137 / 63 \\
4\end{array}$ & 15 & 900 \\
\hline $\begin{array}{l}\text { Lent } \\
\text { ils }\end{array}$ & 75 & 500 & $\begin{array}{l}960 / 0 \\
00\end{array}$ & $\begin{array}{l}9 / 00 \\
0\end{array}$ & $\begin{array}{l}4 / 500 / \\
000\end{array}$ & $\begin{array}{l}3 / 540 / \\
000\end{array}$ & $\begin{array}{l}265 / 500 / 0 \\
00\end{array}$ & $\begin{array}{l}167 / 08 \\
6\end{array}$ & 15 & 1125 \\
\hline $\begin{array}{l}\text { Bea } \\
\text { ns }\end{array}$ & 40 & 500 & $\begin{array}{l}1 / 155 / \\
000\end{array}$ & $\begin{array}{l}12 / 0 \\
00\end{array}$ & $\begin{array}{l}6 / 000 / \\
000\end{array}$ & $\begin{array}{l}4 / 845 / \\
000\end{array}$ & $\begin{array}{l}193 / 800 / 0 \\
00\end{array}$ & $\begin{array}{l}121 / 96 \\
3\end{array}$ & 15 & 600 \\
\hline $\begin{array}{l}\text { Tota } \\
1\end{array}$ & 4332 & - & - & - & - & - & $\begin{array}{l}10 / 725 / 15 \\
5 / 000\end{array}$ & $\begin{array}{l}6 / 749 / \\
625\end{array}$ & - & 4419 \\
5
\end{tabular}

Source: Statistical yearbook of agricultural jihad in Kalat city and the author's calculations in 2018

Note: In wheat, 1400 kilos of straw per hectare, which is priced at 1,400,000 Tomans, which is added to its net income.

According to the results of the above table, the share of each rural household from the income of these products has been $625 / 749.6$ Tomans, of which wheat has the largest share of household income.

\section{Gardening}

Cultivation of fruit trees and their exploitation is one of the pillars of rural economy. The type of tree, the area under cultivation and the amount of harvest are different in different areas of the country (Mahdavi 2008: 187). And each region of Iran is suitable for growing one or more types, especially fruit. (Badiee, 2003: 175).

Table 4 shows the area under cultivation and the amount of income from major horticultural products in the sample villages.

\section{Income and employment from horticulture}

Table 4.

Income from major horticultural products of sample villages During the cropping year 2018-2019 hectares / Tomans

\begin{tabular}{|c|c|c|c|c|c|c|c|c|c|c|}
\hline $\begin{array}{l}\text { The } \\
\text { pro } \\
\text { duct }\end{array}$ & $\begin{array}{l}\text { Area } \\
\text { under } \\
\text { cultiv } \\
\text { ation }\end{array}$ & $\begin{array}{l}\begin{array}{l}\text { Oper } \\
\text { ation }\end{array} \\
\mathrm{Kg}\end{array}$ & $\begin{array}{l}\text { Unit } \\
\text { pric } \\
\text { e - } \\
\text { Tom } \\
\text { ans }\end{array}$ & $\begin{array}{l}\text { Cost } \\
\text { per } \\
\text { hecta } \\
\text { re }\end{array}$ & $\begin{array}{l}\text { Impu } \\
\text { re } \\
\text { incom } \\
\text { e per } \\
\text { hectar } \\
\text { e }\end{array}$ & $\begin{array}{l}\text { Net } \\
\text { income } \\
\text { per } \\
\text { hectar } \\
\text { e }\end{array}$ & $\begin{array}{l}\text { Total } \\
\text { net } \\
\text { income }\end{array}$ & $\begin{array}{l}\text { House } \\
\text { hold } \\
\text { share }\end{array}$ & $\begin{array}{l}\text { Wor } \\
\text { king } \\
\text { day } \\
\text { requi } \\
\text { red }\end{array}$ & $\begin{array}{l}\text { Wor } \\
\text { king } \\
\text { day } \\
\text { creat } \\
\text { ed }\end{array}$ \\
\hline $\begin{array}{l}\text { Appl } \\
\mathrm{e}\end{array}$ & 45 & 5000 & 2500 & $\begin{array}{l}000 / 0 \\
00 / 5\end{array}$ & $\begin{array}{l}000 / 5 \\
00 / 12\end{array}$ & $\begin{array}{l}000 / 50 \\
0 / 7\end{array}$ & $\begin{array}{l}000 / 500 \\
1337\end{array}$ & $\begin{array}{l}398 / 2 \\
12\end{array}$ & 50 & 2250 \\
\hline $\begin{array}{l}\text { Apri } \\
\text { cot }\end{array}$ & 75 & 1500 & 4000 & $\begin{array}{l}000 / 0 \\
00 / 4\end{array}$ & $\begin{array}{l}000 / 0 \\
00 / 6\end{array}$ & $\begin{array}{l}000 / 00 \\
0 / 2\end{array}$ & $\begin{array}{l}000 / 000 \\
/ 150\end{array}$ & $\begin{array}{l}399 / 9 \\
4\end{array}$ & 50 & 3750 \\
\hline $\begin{array}{l}\text { Peac } \\
\text { h }\end{array}$ & 32 & 4000 & 3500 & $\begin{array}{l}000 / 0 \\
00 / 5\end{array}$ & $\begin{array}{l}000 / 0 \\
00 / 14\end{array}$ & $\begin{array}{l}000 / 00 \\
0 / 9\end{array}$ & $\begin{array}{l}000 / 000 \\
/ 288\end{array}$ & $\begin{array}{l}246 / 1 \\
81\end{array}$ & 50 & 1600 \\
\hline $\begin{array}{l}\text { Wal } \\
\text { nut }\end{array}$ & 165 & 1700 & $\begin{array}{l}2500 \\
0\end{array}$ & $\begin{array}{l}000 / 0 \\
00 / 7\end{array}$ & $\begin{array}{l}000 / 5 \\
00 / 42\end{array}$ & $\begin{array}{l}000 / 00 \\
0 / 355\end{array}$ & $\begin{array}{l}000 / 500 \\
/ 857 / 5\end{array}$ & $\begin{array}{l}281 / 6 \\
86 / 3\end{array}$ & 50 & 8250 \\
\hline
\end{tabular}




\begin{tabular}{|l|l|l|l|l|l|l|l|l|l|l|}
\hline $\begin{array}{l}\text { Tota } \\
1\end{array}$ & 317 & - & - & - & - & - & $\begin{array}{l}000 / 000 \\
/ 633 / 6\end{array}$ & $\begin{array}{l}304 / 1 \\
74 / 4\end{array}$ & - & $\begin{array}{l}1585 \\
0\end{array}$ \\
\hline
\end{tabular}

Source: Agricultural Jihad of Kalat city, 2019 and the author's calculations

Based on the results of the table above, the net income of these products is estimated at 633 , 6000,000 Tomans. The share of each rural household in the income of these products is estimated at 4,174,304 Tomans. Walnut product has the largest share of household income.

\section{Conclusion}

Cultivation of medicinal plants has high added value despite low water requirement. In medicinal plants, unlike some agricultural products such as wheat, which grow in large and good lands, it is possible in small lands. Since there are many small lands in Khorasan Razavi province, it is possible to cultivate medicinal plants in these small lands even by rural women. In addition, the resistance of most medicinal plants to drought and saline soils allows farmers in low-rainfall and arid areas to earn a good profit by planting them. Due to the limited water in our country, native medicinal plants can be a good alternative for plants that consume a lot of water.

Most research on economic diversification shows that non-agricultural activities have increased incomes, reduced unemployment and created employment for villagers, and consequently reduced their poverty. Therefore, in this study, the production of medicinal plants as an activity in order to diversify the rural economy in Kalat city has been studied in order to increase income and reduce unemployment and finally, reduce the amount and volume of rural migration.

The results of the present study show that the average income per hectare of pharmaceutical and agricultural products through indicators: Planting cost per hectare, operation per hectare, price per kilogram of crop were calculated, then the average income per hectare of medicinal and agricultural products were compared. Therefore, the results of the table below indicate that the net income of each hectare of medicinal plant products averaged 20,379.375 Tomans and each hectare of agricultural production was 3.268.300 Tomans and comparison of the average income index indicates that medicinal plants have generated $523.6 \%$ more revenue than crops.

Table 5.

Comparison of income generation per hectare of medicinal plants and crops to Tomans During the cropping year 2019-2018

\begin{tabular}{|c|c|c|c|c|c|c|c|}
\hline $\begin{array}{l}\text { Plan } \\
\text { t } \\
\text { type }\end{array}$ & $\begin{array}{l}\text { Plant } \\
\text { name }\end{array}$ & $\begin{array}{l}\text { Planting } \\
\text { cost }\end{array}$ & $\begin{array}{l}\text { Performanc } \\
\text { e } \\
\mathrm{Kg} / \mathrm{h}\end{array}$ & $\begin{array}{l}\text { Price } \\
\text { per } \\
\text { kilo }\end{array}$ & $\begin{array}{l}\text { Net } \\
\text { income } \\
\text { per } \\
\text { hectare }\end{array}$ & $\begin{array}{l}\text { Medium } \\
\text { income }\end{array}$ & $\begin{array}{l}\text { Percentag } \\
\text { e } \\
\text { difference }\end{array}$ \\
\hline \multirow{4}{*}{ : } & Chia & $865 / 000$ & 300 & $\begin{array}{l}20 / 00 \\
0\end{array}$ & $5 / 135 / 000$ & \multirow[t]{4}{*}{$\begin{array}{l}20 / 379 / 37 \\
5\end{array}$} & \multirow[t]{4}{*}{$523 / 6$} \\
\hline & Cumin & $\begin{array}{l}1 / 250 / 00 \\
0\end{array}$ & 400 & $\begin{array}{l}35 / 00 \\
0\end{array}$ & $\begin{array}{l}12 / 75 / 000 \\
0\end{array}$ & & \\
\hline & Sesame & $920 / 000$ & 300 & $\begin{array}{l}22 / 00 \\
0\end{array}$ & $5 / 680 / 000$ & & \\
\hline & Barhag & $\begin{array}{l}1 / 850 / 00 \\
0\end{array}$ & 450 & $\begin{array}{l}22 / 00 \\
0\end{array}$ & $8 / 050 / 000$ & & \\
\hline
\end{tabular}




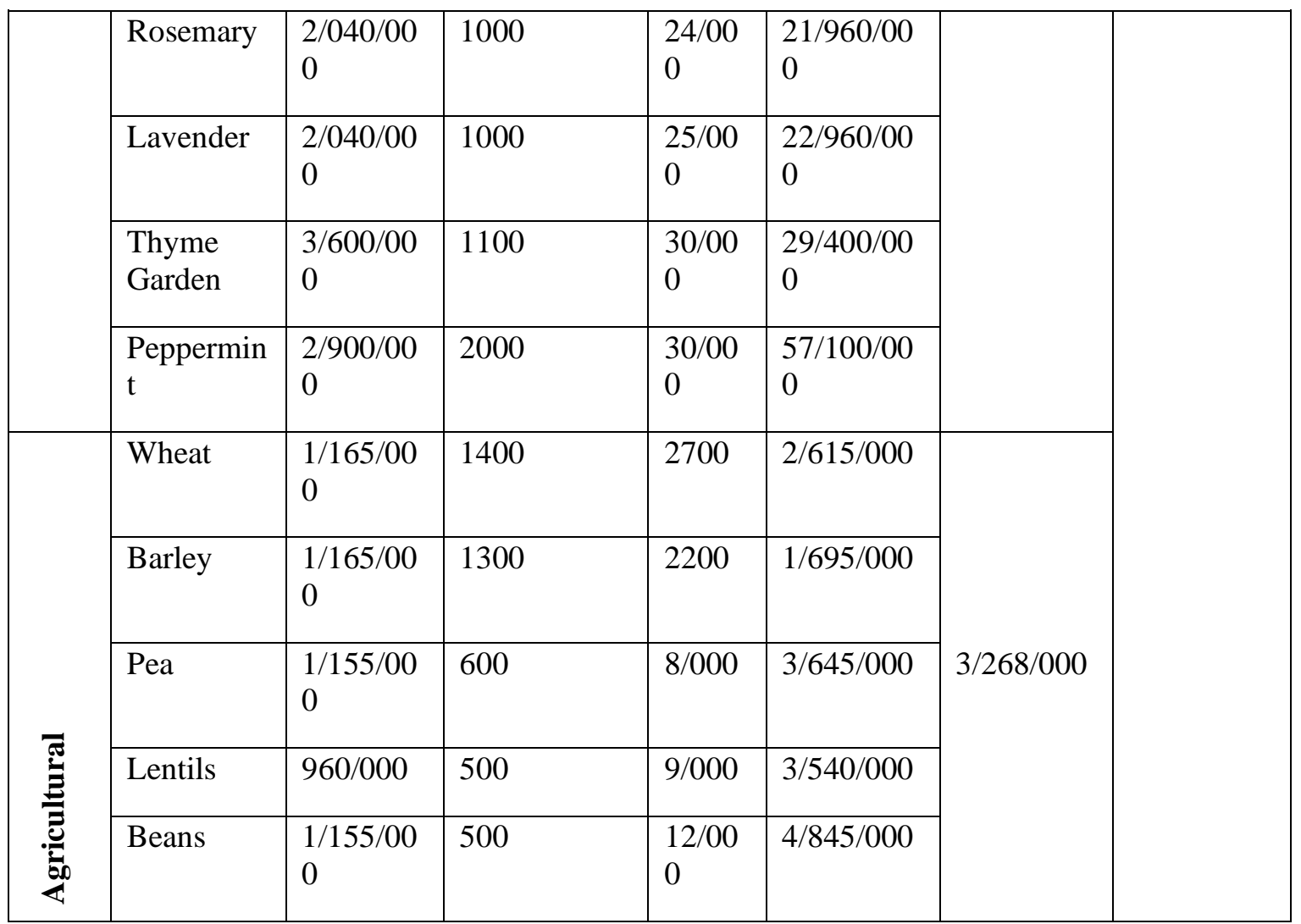

Source: Agricultural Jihad of Kalat city 2019, field studies and author's calculations

\section{Suggestions}

In order to develop the villages economically and solve the problems raised in this article and according to the calculations made in this study, cultivation and production of medicinal plants will create employment and increase rural income Provided that the following solutions are considered:

- To maintain the quality of medicinal plants, the time interval between production and consumption of medicinal plants should be reduced.

- Proper and hygienic supply of medicinal plants increases the consumer's attitude to the use of medicinal plants.

- Extension experts and extension centers should have better cooperation with the villagers.

- Reducing intermediaries in the sale and supply of medicinal plants helps them to be more profitable.

- The use of appropriate machinery and technology leads to increased production efficiency and reduced waste.

- The use of specialists and people trained in agriculture increases the quantity and quality of plant products.

- Granting facilities to the beneficiaries should be done by the responsible institutions and organizations.

- Participate in extension classes organized by experts.

- Visiting production farms in rural areas and talking directly with producers.

- Observance of appropriate standards for packaging of medicinal plants In order to increase people's consumption as well as exports, which will eventually lead to the development of the medicinal plants industry.

- Informing farmers about the benefits of growing medicinal plants.

- In order to reassure the villagers, the production of medicinal plants should be covered by insurance. 


\section{Reference}

Afshar, Z. (2017). Feasibility study of the entry of medicinal plants into the cultivation pattern of creating related conversion industries (Case study: Rural settlement of Chenaran city), PhD Thesis in Geography and Rural Planning, thesis, Ferdowsi University, Supervisor: Ghasemi, Maryam.

Badiee, R. (2003). Detailed Geography of Iran, Iqbal Publications.

Bernath, J. (1999). Biological and economical aspects of utilization and exploitation of wild growing medicinal plants in middle and south Europe. In: Proceedings of the second world congress on medicinal and aromatic plants for welfare. Caffni, N., J. Bernath, L Cracker, A. Jatisatienr \& G. Giberti,(Eds) WOCMAPII. Biological resources, Sustanable use, Conservation and Ethnobotany.

Fattahi, M, Fattahi,B. February. (2010). Basics of Medicinal Plants, Book, Tehran University Jihad.

Heidari, Gh, Jahannama, F. (2003). Women's Abilities in Rural Agriculture, Women's Research Quarterly, 1(6), 68-77.

Javan, J, Alavizadeh, S. A, Kermani, M. (2011). The Role of Diversification of Economic Activities in Sustainable Rural Development (Case Study: Semirom County), Iranian Geographical Association, Geography Quarterly, 9(29), 89-99.

Kashfi Bonab, As R.. (2010). Comparative Economic Advantage of Cultivation and Trade of Medicinal Plants in Iran and Its Value in Global Markets, Green Zool Journal, 11, 134145 .

Kouchaki, A, Nasiri Mahallati, M, Najafi, F. (2006). Biodiversity of medicinal and aromatic plants in the ecosystem of Iranian cropping systems, Green Zool Journal, 12, 29-45.

Labashchi, M. H. (2017). Water Crisis and the need to develop the cultivation of medicinal plants, Agricultural Research, Education and Extension Organization, 3(3), 10-19.

Matiei Langroudi, S H, Faraji Sabkbar, H A, Hojjat Shamami, S. (2019). Analysis of Barriers and Diversification Capabilities of Activities in Rural Economy Case: Rahmatabad and Blocks of Rudbar, Journal of Space Economics and Rural Development, 8(1), 89-120.

Mazaheri, D, Majnoon Hosseini, N. (2001). Fundamentals of General Agriculture, University of Tehran Press, First Edition.

Moaveni, P. (2009). Medicinal Plants, Volume 1, Publisher of Islamic Azad University, Ghods Branch.

Omidbeigi, R. (2011). Production and processing of medicinal plants, sixth edition, Astan Quds Razavi Publications.

Sen, T., and Samanta, S.K. (2014). Medicinal plants, human health and biodiversity: a broad review. In Biotechnological Applications of Bidiversity. Springer Berlin Heidelberg.

Statistical Yearbook of Khorasan Razavi Province. (2016). Management and Planning Organization of Khorasan Razavi Province, Deputy of Statistics and Information.

Taghavi, N. (2009). Principles of Demography of Tabriz, Research Society and Daniel, Fourth Edition. 
Tarhani, A. (2015). Diversification of Rural Economy with the Approach of Medicinal Plants Production (Case Study of Villages in Quchan County), PhD Thesis in Geography and Rural Planning, Thesis, Azad University, Mashhad Branch, Supervisor: Jafari, Hamid.

Yasouri, M, Javan, F. (2015). Analysis of Restrictions on Diversification of Rural Economy Case: Eshkor Olya County, Quarterly Research Zahedan Journal, 17, 67-88. 